\title{
The Quality of Life Chronic Renal Failure (CRF) Patients in Hemodialysis Unit at District General Hospital Pringsewu Regency Lampung Province in 2018
}

\author{
Virna Widora Saputri ${ }^{1, *}$, Rico Januar Sitorus ${ }^{2}$, and H. M. Zulkarnain ${ }^{2}$ \\ ${ }^{1}$ S2 Student in Epidemiology and Biostatistics, Public Health Faculty Universitas Sriwijaya \\ ${ }^{2}$ Lecturer at Public Health Faculty Universitas Sriwijaya
}

\begin{abstract}
The purpose of this study was to determine the factors that affect the quality of life of CRF patients in Hemodialysis Unit at Pringsewu District General Hospital. This study was conducted from February to May 2018 with cross sectional study design. The sampling technique using total sampling technique. Measurement of quality of life using KDQOL-SFTM version 1.3. The results found that quality of life scores were quite low in some domains and subscales. The mean of total score was $55.70 \pm 21.30$ with mean of Physical Health Composite $(\mathrm{PHC})=$ $38.85 \pm 9.26$ and mean of Mental Health Composite $(\mathrm{MHC})=36.13 \pm$ 7.08. Regarding the targeted area of ESRD, the scale of renal disease burden and occupational status scale resulted in the lowest score. The sleep quality scale score was $56.18 \pm 20.72$. Only 61 patients responded to questions of sexual activity with a score of $55.53 \pm 27.44$ on the scale of sexual function. In the 36-item health survey, the mean total score was $45.90 \pm 21.95$. The lowest score represented the limitations of roles caused by physical and emotional health problems. The result of statistical test showed that the variables significantly related to the quality of life of CRF patients were age, income, duration of hemodialysis and family support. Thus, family support was the variable that had the greatest impact on determining the quality of life of CRF patients. The CRF patients who lacked family support were 4.6 times more likely to lead poorer life compared to CRF patients who received good family support after being controlled by age, income, duration of hemodialysis, gender, working status, and diabetes mellitus variables.
\end{abstract}

\section{Introduction}

Chronic Renal Failure (CRF) is still a public health problem worldwide today. The estimated prevalence of overall chronic renal failure was about $8 \%-16 \%$ or nearly 500 million affected individuals, of whom 78\% (387.5 million) were in low-income and middleincome countries (LMICs). Between 1990 and 2010, deaths caused by Chronic Kidney

*Corresponding authors: rico_januar@fkm.unsri.ac.id 
Disease (CKD) were nearly doubled, and were ranked 18th cause of death in 2012 [3]. According to the United State Renal Data System, in the United States, the prevalence of chronic renal failure increased by $14.8 \%$ in $2011-2014$, with stage 3 . It was estimated that more than 20 million (more than 10\%) adults in the United States had Chronic Kidney Disease per year [7]. The increase in cases of kidney disease in the world occurs every year by more than $50 \%$. In Indonesia, the prevalence of CRF based on a doctor's diagnosis was $0.2 \%$ and in Lampung the prevalence was $0.3 \%$ [6]. The Indonesian Renal Registry (IRR) data showed that patients with Chronic Renal Failure or Terminal/ ESRD were the most patients (89\%) followed by Acute Renal Failure / ARF patients (7\%), and Acute Renal Failure patients in CRF (4\%). They must undergo hemodialysis to survive.

Hemodialysis or kidney transplantation is not a cheap action. The cost of treatment in prolonging the life of chronic renal failure patients who have reached the final stage will certainly increase health costs. The number of cases distribution and claim fee at BPJS Advanced Outpatient Care (RJTL) by 2016, for urinary system disease reached 3,198,267 cases, the third highest by spending more than Rp 3.052.691.160.100 (Three trillion fifty two billion six hundred ninety one million one hundred sixty thousand one hundred rupiahs) [2].

Besides impacting considerable health financing, hemodialysis also affects the patient's quality of life. World Health Organization WHO itself has formulated four dimensions of quality of life namely physical dimension, psychological dimension, social dimension and environmental dimension. These four dimensions have been able to describe the quality of life of patients with chronic renal failure with hemodialysis therapy who have different religions, ethnicities and cultures [8].

Many factors affect the quality of life of CRF patients, one of it is family support. The presence of family members who accompany the patient during hemodialysis therapy, causing the patient to feel noticed, although not all family members, but alternately or family members who have more time seen during therapy. Such family support has an impact on patient compliance in performing hemodialysis therapy. A study of 72 patients with Chronic Kidney Disease (CKD) at RSU Haji Surabaya concluded that the quality of life of patients was influenced by the support they received and the status of diabetes mellitus [1].

\section{Materials and Methods}

This research used observational analytic research with cross sectional research design, in Hemodialysis Unit at Pringsewu District General Hospital of Pringsewu Regency. The study was conducted in February-May 2018. Population of the study was all patients of Chronic Renal Failure (CRF) in Hemodialysis Unit at Pringsewu District General Hospital of Pringsewu Regency in 2018. The sampling technique using total sampling technique, consisted of 117 participants. Independent variables to be studied were age, sex, education, employment status, income, duration of hemodialysis, Hb level, DM status, and family history of hypertension and family support.

The types of data collected were primary and secondary data. Primary data were obtained from interviews using sociodemographic questionnaires, family support questionnaires and Kidney Disease Quality of Life-Short Form (KDQOL-SFTM version 1.3) questionnaires with a range of values from 0-100 [5]. While the secondary data were in the form of research subject, by looking at patient status and diagnosis of patient's disease in Medical Record in Hemodialysis Unit at Pringsewu District General Hospital of Pringsewu Regency in 2018. The test result of validity and reliability of instrument 
KDQOL-SFTM version 1.3 and instrument of family support caused internal consistency and coefficient reliability (Cronbach's alpha) of 0.941 and 0.937 respectively. There were three data analyzes: univariate analysis, bivariate analysis using chi-square test, with $\alpha=$ 0.05 and $95 \%$ confidence interval value as well as multivariate analysis using multiple logistic regression [4].

This research was conducted after going through ethical review procedure and got ethical statement and was approved to be executed from Health Research Ethics Commission (KEPK) of Public Health Faculty of Sriwijaya University by issuing Ethical Approval Certificate (Number 91 / UN9.1.10 / KKE / 2018) on May 3, 2018.

\section{Results and Discussions}

Table 1. KDQOL SF-1.3 scores for all studied patients

\begin{tabular}{|c|c|c|c|c|}
\hline Scales & Mean & \multicolumn{1}{l|}{ Median } & SD & n \\
\hline Kidney disease targeted scales & 70.12 & 72.92 & 19.75 & 117 \\
\hline Symptoms/problems (12) & 70.14 & 75.00 & 19.71 & 117 \\
\hline Effect of kidney disease (8) & 37.02 & 25.00 & 25.63 & 117 \\
\hline Burden of kidney disease (4) & 41.03 & 50.00 & 31.22 & 117 \\
\hline Work status (2) & 80.74 & 86.67 & 15.82 & 117 \\
\hline Cognitive function (3) & 73.96 & 73.33 & 15.39 & 117 \\
\hline Quality of social interaction (3) & 55.53 & 50.00 & 27.44 & 61 \\
\hline Sexual function (2) & 56.18 & 57.50 & 20.72 & 117 \\
\hline Quality of Sleep (4) & 74.93 & 66.67 & 21.40 & 117 \\
\hline Social support (2) & 82.16 & 75.00 & 11.53 & 117 \\
\hline SF-36 survey scale items & 49.44 & 50.00 & 22.18 & 117 \\
\hline Quality of Dialysis staff services (2) & 59.12 & 50.00 & 19.88 & 117 \\
\hline Patient satisfaction (1) & 17.09 & 0.00 & 33.26 & 117 \\
\hline Physical function 10) & 65.26 & 67.50 & 24.13 & 117 \\
\hline Role physical (4) & 50.85 & 50.00 & 16.22 & 117 \\
\hline Pain perception (2) & 34.46 & 36.00 & 18.65 & 117 \\
\hline General health (5) & 17.66 & 0.00 & 32.92 & 117 \\
\hline Emotional well-being (5) & 66.35 & 75.00 & 23.30 & 117 \\
\hline Role emotional (3) & 51.54 & 55.00 & 13.90 & 117 \\
\hline Social function (2) & 60.43 & 60.00 & 12.96 & 117 \\
\hline Energy/Fatigue (4) & $\mathbf{5 5 . 7 0}$ & $\mathbf{5 3 . 7 8}$ & & $\mathbf{2 1 . 3 0}$ \\
\hline Overall health (1) & 38,85 & 38.41 & 9.26 & 117 \\
\hline Total Score & 36.13 & 37.07 & 7.08 & 117 \\
\hline SF-12 Physical Health Composite & \multicolumn{1}{|}{}
\end{tabular}


Table 2. Distribution of Respondents

\begin{tabular}{|c|c|c|}
\hline Variables & Number & Percentage (\%) \\
\hline \multicolumn{3}{|c|}{ Age } \\
\hline$\leq 52$ years & 62 & 53 \\
\hline$>52$ years & 55 & 47 \\
\hline \multicolumn{3}{|c|}{ Gender } \\
\hline Male & 58 & 49.6 \\
\hline Female & 59 & 50.4 \\
\hline \multicolumn{3}{|c|}{ Education } \\
\hline High (SMA, PT) & 54 & 46.2 \\
\hline Low (SD, SMP) & 55 & 47.0 \\
\hline None & 8 & 6.8 \\
\hline \multicolumn{3}{|c|}{ Working status } \\
\hline Working & 58 & 49.6 \\
\hline Not working & 59 & 50.4 \\
\hline \multicolumn{3}{|c|}{ Total income } \\
\hline$>$ Rp1.908.447,50 & 34 & 29.1 \\
\hline$\leq \mathrm{Rp} 1.908 .447,50$ & 83 & 70.9 \\
\hline \multicolumn{3}{|c|}{ Duration of Hemodialysis therapy } \\
\hline Long $(\geq 11$ bulan $)$ & 87 & 74.4 \\
\hline Not long yet $(<11$ bulan $)$ & 30 & 25.6 \\
\hline \multicolumn{3}{|c|}{ Hemoglobin level } \\
\hline Not anemia ( > $10 \mathrm{gr} / \mathrm{dl})$ & 6 & 5.1 \\
\hline Anemia $(\leq 10 \mathrm{gr} / \mathrm{dl})$ & 111 & 94.9 \\
\hline \multicolumn{3}{|c|}{ DM Status } \\
\hline Not Diabetes $(<126 \mathrm{mg} / \mathrm{dL})$ & 86 & 73.5 \\
\hline Diabetes $(\geq 126 \mathrm{mg} / \mathrm{dL})$ & 31 & 26.5 \\
\hline \multicolumn{3}{|c|}{ History of Hypertension } \\
\hline No $(<140 / 90 \mathrm{mmHg})$ & 36 & 30.8 \\
\hline Yes $(\geq 140 / 90 \mathrm{mmHg})$ & 81 & 69.2 \\
\hline \multicolumn{3}{|c|}{ Family support } \\
\hline Good & 42 & 35.9 \\
\hline Not good & 75 & 64.1 \\
\hline \multicolumn{3}{|c|}{ Marital Status } \\
\hline Married & 106 & 90.6 \\
\hline Single & 5 & 4.3 \\
\hline Widowed & 6 & 5.1 \\
\hline \multicolumn{3}{|c|}{ Race } \\
\hline Lampungnese & 7 & 6.0 \\
\hline Javanese & 95 & 81.2 \\
\hline Semendonese & 6 & 5.1 \\
\hline Others & 9 & 7.7 \\
\hline \multicolumn{3}{|c|}{ Comorbidities } \\
\hline Unknown & 14 & 12.0 \\
\hline Hypertension & 81 & 69.2 \\
\hline Polycystic Kidney Disease & 5 & 4.3 \\
\hline Kidney stone & 14 & 12.0 \\
\hline Preeclampsia & 1 & 0.9 \\
\hline Primary Glomerulopathy (GNC) & 2 & 1.7 \\
\hline \multicolumn{3}{|c|}{ Most often accompany HD therapy } \\
\hline Husband/Wife & 70 & 59.8 \\
\hline Children/Nephew & 33 & 28.2 \\
\hline Father/Mother & 4 & 3.4 \\
\hline Brother/Sister & 2 & 1.7 \\
\hline None & 8 & 6.8 \\
\hline \multicolumn{3}{|c|}{ Membership of BPJS } \\
\hline Yes & 117 & 100.0 \\
\hline
\end{tabular}


Table 3. Distribution of Quality of Life According to Independent Variables under Study

\begin{tabular}{|c|c|c|c|c|c|c|c|c|}
\hline \multirow{3}{*}{ Variables } & \multicolumn{4}{|c|}{ Quality of life } & \multirow{2}{*}{\multicolumn{2}{|c|}{ Total }} & \multirow{3}{*}{$\begin{array}{c}P \\
\text { Value }\end{array}$} & \multirow{3}{*}{ OR } \\
\hline & \multicolumn{2}{|c|}{ Good } & \multicolumn{2}{|c|}{ Not good } & & & & \\
\hline & $\mathbf{N}$ & $\%$ & $\mathbf{n}$ & $\%$ & $\mathbf{N}$ & $\%$ & & \\
\hline Age: & & & & & & & & \\
\hline Young ( $\leq 52$ years) & 32 & $51.60 \%$ & 30 & $48.40 \%$ & 62 & $100 \%$ & 0.013 & 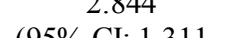 \\
\hline Old (> 52 years) & 15 & $27.30 \%$ & 40 & $72.70 \%$ & 55 & $100 \%$ & & $\begin{array}{c}95 \%(73) \\
6.173)\end{array}$ \\
\hline Gender: & & & & & & & & \\
\hline Male & 27 & $46.60 \%$ & 31 & $53.40 \%$ & 58 & $100 \%$ & (2) 227 & $\begin{array}{c}1.698 \\
(050 \% \text { I. } 0805\end{array}$ \\
\hline Female & 20 & $33.90 \%$ & 39 & $66.10 \%$ & 59 & $100 \%$ & 0.227 & $\begin{array}{c}(95 \%(1.0 .805- \\
3.582)\end{array}$ \\
\hline Education: & & & & & & & & \\
\hline High & 22 & $40.70 \%$ & 32 & $59.30 \%$ & 54 & $100 \%$ & & \\
\hline Low & 23 & $41.80 \%$ & 32 & $58.20 \%$ & 55 & $100 \%$ & & 0.957 \\
\hline None & 2 & $25 \%$ & 6 & $75 \%$ & 8 & $100 \%$ & 0.659 & 2.062 \\
\hline $\begin{array}{l}\text { Working Status: } \\
\text { Working }\end{array}$ & 30 & $5170 \%$ & 28 & $48,30 \%$ & 58 & $100 \%$ & & 2.647 \\
\hline Not working & 17 & $28.80 \%$ & 42 & $71.20 \%$ & 59 & $100 \%$ & 0.019 & $\begin{array}{c}\text { (95\% CI: } 1.234 \text { - } \\
5.679)\end{array}$ \\
\hline Income: & & & & & & & & 4.253 \\
\hline$>$ Rp1.908.447.50 & 20 & $58.8 \%$ & 14 & $41.2 \%$ & 34 & $100 \%$ & 0001 & (95\% CI. 1886 - \\
\hline$\leq \mathrm{Rp} 1.908 .447 .50$ & 27 & $32.5 \%$ & 56 & $67.5 \%$ & 83 & $100 \%$ & 0.001 & $9.905)$ \\
\hline $\begin{array}{c}\text { Duration of HD } \\
\text { therapy: }\end{array}$ & & & & & & & & \\
\hline Long ( $\geq 11$ month) & 41 & $47.1 \%$ & 46 & $52.9 \%$ & 87 & $100 \%$ & 0017 & $\begin{array}{c}3.503 \\
(95 \% \text { CI. } 1326-2\end{array}$ \\
\hline $\begin{array}{c}\text { Not long yet }(<11 \\
\text { month })\end{array}$ & 6 & $20 \%$ & 24 & $80 \%$ & 30 & $100 \%$ & 0.017 & $\begin{array}{l}9.582) \\
9\end{array}$ \\
\hline Hemoglobin level: & & & & & & & & \\
\hline Not anemia ( > 10 & 4 & $66.7 \%$ & 2 & $33.3 \%$ & 6 & $100 \%$ & (25? & 3.163 \\
\hline $\begin{array}{c}\mathrm{gr} / \mathrm{dl}) \\
\text { Anemia }(\leq 10 \mathrm{gr} / \mathrm{dl})\end{array}$ & 43 & $38.7 \%$ & 68 & $61.3 \%$ & 111 & $100 \%$ & 0.352 & $\begin{array}{c}(95 \% \text { C1: 0.J55 - } \\
18.016)\end{array}$ \\
\hline DM Status: & & & & & & & & \\
\hline $\begin{array}{c}\text { Not Diabetes }(<126 \\
\mathrm{mg} / \mathrm{dL})\end{array}$ & 40 & $465 \%$ & 46 & $535 \%$ & & & & 2.981 \\
\hline $\begin{array}{c}\text { Diabetes }(\geq 126 \\
\mathrm{mg} / \mathrm{dL})\end{array}$ & $\begin{array}{c}40 \\
7\end{array}$ & $22.6 \%$ & 24 & $77.4 \%$ & 31 & $100 \%$ & 0.034 & $\begin{array}{c}\text { (95\% CI: } 1.162- \\
7.652)\end{array}$ \\
\hline History of & & & & & & & & \\
\hline $\begin{array}{c}\text { Hypertension: } \\
\text { No }(<140 / 90 \mathrm{mmHg})\end{array}$ & 15 & $417 \%$ & 21 & $583 \%$ & 36 & $100 \%$ & & 1.094 \\
\hline $\begin{array}{c}\text { Yes }(\geq 140 / 90 \\
\text { mmHg })\end{array}$ & 32 & $39.5 \%$ & 49 & $60.5 \%$ & 81 & $100 \%$ & 0.987 & $\begin{array}{c}\text { (95\%CI: } 0.492- \\
2.430)\end{array}$ \\
\hline $\begin{array}{c}\text { Family support } \\
\text { Good }\end{array}$ & 23 & $62.2 \%$ & 14 & $37.8 \%$ & 37 & $100 \%$ & & 3.833 \\
\hline Not good & 24 & $30 \%$ & 56 & $70 \%$ & 80 & $100 \%$ & 0.002 & $\begin{array}{c}\text { (95\%CI: } 1.691- \\
8.691)\end{array}$ \\
\hline
\end{tabular}

\footnotetext{
${ }^{*}$ Chi Square Test
}

From Table 4, it can be seen that $\mathrm{p}$ value $>0.25$ for educational variables, hemoglobin level and history of hypertension, so it was not included in multivariate analysis. While for the variable with value $p$ value $<0.25$ can be directly proceeded to multivariate analysis and got the final model as follows (after interaction test): 
Table 4. Multiple Logistic Regression Final Model

\begin{tabular}{|c|c|c|c|c|c|c|}
\hline \multirow{2}{*}{ Independent Variables } & \multirow{2}{*}{ B } & \multirow{2}{*}{ S.E } & \multirow{2}{*}{ p value } & \multirow{2}{*}{ OR } & \multicolumn{2}{|c|}{ 95\% CI } \\
\cline { 6 - 7 } & & & & Lower & Upper \\
\hline Age & 1.336 & 0.496 & 0.007 & 3.803 & 1.440 & 10.044 \\
\hline Gender & 0.391 & 0.493 & 0.427 & 1.479 & 0.563 & 3.884 \\
\hline Working status & 0.791 & 0.495 & 0.110 & 2.205 & 0.835 & 5.819 \\
\hline Income & 1.153 & 0.506 & 0.023 & 3.168 & 1.176 & 8.533 \\
\hline Duration of HD therapy & 1.224 & 0.609 & 0.044 & 3.401 & 1.031 & 11.211 \\
\hline DM status & 0.870 & 0.591 & 0.141 & 2.387 & 0.750 & 7.594 \\
\hline Family support & 1.521 & 0.503 & 0.002 & 4.576 & 1.709 & 12.257 \\
\hline Constanta & -3.054 & & & & & \\
\hline
\end{tabular}

\subsection{Quality of Life}

Based on table 1 above, from $117 \mathrm{HD}$ patients studied (58 men +59 women), most of them aged $51.52 \pm 11.8$ years, a fairly low HRQOL score appeared in some domains and subscales. The mean of total score was $55.70 \pm 21.30$ (out of 100 points), so the mean of Physical Health Composite $(\mathrm{PHC})=38.85 \pm 9.26$ and the mean of Mental Health Composite $(\mathrm{MHC})=36.13 \pm 7.08$. Regarding the targeted area of ESRD, the mean total score was $63.72 \pm 20.77$, the highest score was for the dialysis staff support scale $(82.16 \pm$ $11.53)$ followed by the cognitive function scale $(80.74 \pm 15.82)$ and social support scale $(74.93 \pm 21.40)$. However, the renal disease burden scale and the employment status scale resulted in the lowest scores $(37.02 \pm 25.63$ and $41.03 \pm 31.22$ respectively). The sleep quality scale score was $56.18 \pm 20.72$. Only 61 patients responded to questions of sexual activity with a score of $55.53 \pm 27.44$ on the scale of sexual function. In the 36 -item health survey, the mean total score was $45.90 \pm 21.95$. The social function gave the highest score $(66.35 \pm 23.30)$. The lowest score represents the limitations of roles caused by physical and emotional health problems $(17.09 \pm 33.26$ and $17.66 \pm 32.92)$.

\subsection{Family Support}

Based on the multivariate analysis, the most influencing variable on the determination of quality of life for patients with CRF was family support $(\mathrm{OR}=4.6)$, meaning that patients with CRF who lacked family support were at risk of 4.6 times living a life less qualified compared to patients with CRF who received support from family well after being controlled by age, income, duration of hemodialysis, gender, working status and diabetes mellitus. It was known, family support consisted of four dimensions: the instrumental dimension, the informational dimension, the emotional dimension and the assessment dimension. If these four dimensions were well established then it will synergize positively to the quality of life of patients with CRF. Based on the results of the study found that only $1 / 3$ patients or equal to $35.9 \%$ of patients were with good family support while the remaining $2 / 3$ were still with poor support from families. But in terms of assisting the implementation of dialysis, was good enough. They were routinely always accompanied by families when undergoing hemodialysis therapy. Proved 70 patients $(59.8 \%)$ most often delivered by their spouses, 33 patients $(28.2 \%)$ delivered by their children, 4 patients (3.4\%) delivered by their parents, 2 patients $(1.7 \%)$ delivered by their brother/ sister. Even so there were 8 patients $(6.8 \%)$ who went to the hospital themselves. These eight patients went to the hospital with using their own vehicle, there were also by foot because the 
distance between the house and the hospital was not too far away and there were also leaving together with other patients because their homes were close.

According to the researcher, should the eight patients were still delivered and accompanied in the implementation of dialysis as a form of support from the family. In addition, in case of something undesirable such as the condition of the patient were suddenly down/ unconscious because of the decreased sugar levels, the family accompanying the patient can monitor the patient's condition immediately, minimize the possible emotional effects, and have the right to make a decision for better remedial measures (although at the beginning of dialysis, the family has already signed a letter willing to accept medical treatment in accordance with procedures for patient safety).

Family support has an important effect on the treatment of various types of chronic diseases including hemodialysis patients, where family support can improve the health of hemodialysis patients and is associated with depression, perception of the effects of illness or treatment, and satisfaction in life. The following examples was a piece of interview with one of a female patient initial $\mathrm{X}$ who have had tuberculosis, as a description of the patient's condition regarding the support of the family they received and support from the surrounding community.

It was shown that $\mathrm{X}$ patient got less attention from their children. She never fainted while taking ablution and when conscious she was still in the original position, whereas patient $\mathrm{X}$ and her son were in the same house. There was disappointment at being ignored. There was a feeling of depression and being a burden on the family in old age. "X patients expressed her concerns to her husband because she felt she could not make her husband happy anymore so there was a feeling of resignation if her husband remarries". On the other hand, the lack of support from the surrounding environment makes the patient more depressed. This was seen when the patient is attending the mosque, when the patient tries to sit with other mothers, the patient $\mathrm{X}$ was shunned (no one wants to sit close) until X patient finally spend more time at home and this can certainly worsen the condition physical and psychological of the patient.

\section{Conclusion}

Based on the multivariate analysis, the significant variables related to the quality of life of patients with CRF were age, income, duration of hemodialysis and family support. The variable that most influence on the determination of the quality of life of patients with CRF was family support with $\mathrm{OR}=4.6$. This means that $\mathrm{CRF}$ patients who get lack support family are 4.6 times more likely to lead a less qualified life compared with patients with CRF who get good family support. It was expected that nurses in the Hemodialysis Unit work together with doctors, nutritionists and other health teams to provide education about diabetes mellitus and hypertension holistically, as well as counseling to HD patients and their families as a form of supportive therapy (health promotion once a week).

\section{References}

1. Bestari, A.W. Factors related to the quality of life of hemodialysis chronic kidney disease patients based on whoqol-bref (Research at Hemodialysis Installation of Surabaya, Haji Hospital, 2015) (Doctoral dissertation, Airlangga University, 2015)

2. BPJS. The role of health bpjs in improving health services, (2017) 
3. George, C., Mogueo, A., Okpechi, I., Echouffo-Tcheugui, J.B. and Kengne, A.P. BMJ Global Health 2, 10 (2017)

4. Hastono, S. P. Data Analysis in the Health Sector (Jakarta, Rajawali Pers, 2016)

5. Hays, R., Kallich, J., Mapes, D., Coons, S., Amin, N dan Carter, W. Kidney Disease Quality of Life Short Form (1997)

6. Ministry of Health of the Republic of Indonesia. Basic Health Research (RISKESDAS). (Health Research and Development Agency, Jakarta, Balitbangkes, 2013)

7. United States Renal Data System. USRDS Annual Data Report: Epidemiology of Kidney Disease in the United States Volume 1: CKD in the United State (2016)

8. World Health Organization. The World Health Organization Quality of Life (2004) 